\title{
SOSIALISASI MITIGASI BENCANA BANJIR MELALUI PENANAMAN POHON DI KENAGARIAN SUNGAI DURIAN KABUPATEN PADANG PARIAMAN
}

\section{SOCIALIZATION OF FLOOD DISASTER MITIGATION THROUGH PLANTING TREE IN KENAGARIAN DURIAN RIVER OF PADANG PARIAMAN DISTRCIT}

\author{
Nefilinda, Ade Irma Suryani, Slamet Rianto dan Elvi Zuriyani \\ Program Studi Pendidikan Geografi, STKIP PGRI Sumatera Barat \\ Jalan Gunung Pangilun No.1 Kota Padang, Provinsi Sumatra Barat \\ Alamat korespondensi : nefilinda@yahoo.com \\ (Tanggal Submission: 15 Februari 2020, Tanggal Accepted: 27 April 2020)
}

\begin{abstract}
ABSTRAK
Kenagarian Sungai Durian merupakan kawasan yang rawan terkena bencana banjir. Hal tersebut karena lokasinya yang berada di sekitar Daerah Aliran Sungai (DAS). Masyarakat setempat juga masih memiliki pengetahuan yang rendah tentang pegelolaan DAS sehingga menyebabkan kebanyakan mereka dalam hal memanfaatkan DAS tersebut lebih cenderung mementingkan kepentingan pribadi dibandingkan dengan kepentingan bersama. Salah satu contohnya adalah masih banyaknya masyrakat setempat yang melakukan aktifitas penambangan sirtukil dan penebangan pohon di sekitar DAS, hal ini dapat berdampak terhadap badan sungai ketika terjadi hujan lebat dan dalam waktu yang cukup lama. Kebanyakan masyarakat sebagai petani dan penambang sirtukil sebagai penghasilan tambahan, menurut Wali Nagari Sungai Durian (2018). Perlu adanya sosialisasi mitigasi bencana banjir melalui penenaman pohon sebagai upaya untuk mengurangi dan memperkecil bencana banjir secara tepat dan cepat. Metode yang digunakan untuk melaksanakan kegiatan pengabdian kepada masyaakat ini adalah sosialisasi dan aksi penanaman pohon. Sosialisasi terlaksana dengan baik karena ada kerjasama dengan mitra yaitu Wali Nagari Sungai Durian. Sosialisasi dilakukan kepada masyarakat langsung ke rumah-rumah yang berada di sekitar DAS sehingga mereka menanam bibit di lahan miliknya. Penanaman pohon juga di lakukan di tanah kosong milik kaum di pinggiran sungai. Masyarakat dapat memahami pentingnya penanaman pohon di pinggiran sungai setelah dilakukan sosialisasi mitigasi bencana banjir melalui penanaman pohon.
\end{abstract}

Kata Kunci: sosialisasi, mitigasi bencana banjir, penanaman pohon

\section{PENDAHULUAN}

Menurut Undang-undang Republik Indonesia nomor 4 Tahun 2007 tentang Penanggulangan Bencana, bencana merupakan rangkaian peristiwa yang mengancam dan mengganggu kehidupan dan penghidupan masyarakat disebabkan oleh faktor alam dan/atau non alam maupun faktor manusia sehingga mengakibatkan timbulnya korban jiwa manusia, kerusakan lingkungan, kerugian harta benda dan dampak psikologis. Bencana banjir merupakan salah satu jenis bencana yang berdasarkan Data Informasi Bencana Indonesia (DIBI) paling banyak terjadi dan cenderung meningkat beberapa tahun terakhir. Sedangkan menurut Paimin, dkk (2009), banjir merupakan peristiwa debit aliran air sungai yang secara relatif lebih besar dari biasanya/normal akibat hujan yang turun di hulu atau di suatu tempat tertentu secara terus menerus, sehingga tidak dapat ditampung oleh alur sungai yang ada, maka air meluap keluar dan menggenangi daerah sekitarnya. Daerah 
rawan bencana banjir yang akan dilakukan penyuluhan adalah Nagari Sungai Durian, Kecamatan Patamuan, Kabupaten Padang Pariaman. Nagari ini mempunyai luas $11,84 \mathrm{~km} 2$. terdiri dari $14 \mathrm{RW}$ dengan jumlah penduduk 4.927 jiwa, terdiri dari laki-laki 2.410 dan perempuan 2.517 (Data Kecamatan Patamuan Dalam Angka Tahun 2017). Kondisi masyarakat di Kelurahan Pasie Nan Tigo kebanyakan bermata pencaharian sebagai bertani. Masih banyak pengangguran yang ada di Nagari ini, hal ini terjadi karena kurangnya lapangan pekerjaan, kurangnya keterampilan khusus yang dimiliki oleh masyarakat, tidak adanya modal usaha untuk melakukan usaha mandiri. Banyaknya pengangguran ini akan berdampak terhadap kemiskinan sehingga masyarakat tidak memperdulikan bencana banjir yang akan menghadang mereka. Masyarakat lebih mementingkan mencari pemenuhan kebutuhan hidupnya dari pada mempedulihan mitigasi bencana banjir. Walaupun mereka tinggal di lokasi daerah rawan bencana berupa banjir. Pada hal pemerintah sudah pernah melakukan pemberitahuan tentang pentingnya melakukan pengelolaan DAS.

Nagari Sungai Durian berada pada daerah rawan banjir, sehingga membuat sebagian rumah masyarakat terendam air bahkan banyak perabotan berupa elektronik yang tidak dapat digunakan lagi, hal ini tidak membuat mereka menyerah, akan tetapi masyarakat tetap tinggal di rumah tersebut. Kebanyakan masyarakat bermata pencaharian sebagai petani, jika hasil tai yang mereka peroleh belum bias langsung digunakan untuk memenuhi kebutuhan akan tetapi menunggu berbuah dahulu, maka petani ada yang memanbah pekerjaannya menjadi buruh penambangan sirtukil. Akan tetapi penghasilan mereka masih dibawah rata-rata karena usaha ini hanya Bertani dan membutuhkan waktu dalam menghasilkan tanaman tersebut.

Rendahnya pengetahuan dan pemahaman masyarakat ini terkait dengan kemiskinan, rendahnya pendidikan, rendahnya keahlian, penguasaan teknologi yang terbatas, sehingga membuat masyarakat terbatas dalam mencari tambahan pemenuhan kehidupan. Jenis pekerjaan masyarakat kebanyakan adalah sebagai bertani. Hasil tani yang mereka olah tidak dapat langsung mereka peroleh atau bahkan kurang dalam memenuhi kebutuhan sehari-hari, kerena kurangnya pengetahuan, pemahanan bahkan Pendidikan terkait pengelolaan DAS. Juga disebabkan kurangnya mendapat sosialisasi dari pihak terkait baik pemerintah maupun pihak lainnya.

Oleh karena Nagari Sungai Durian berada di sekitar DAS, maka masyarakat yang tinggal disana rawan terhadap kejadian bencana banjir yang mengancam kehidupan mereka, maka perlu dilakukan sosialisasi mitigasi bencana banjir memalui penanaman pohon di Kenagarian Sungai Durian Kecamatan Patamuan Kabupaten Padang Pariaman.

\section{METODE KEGIATAN}

Metode yang digunakan dalam melaksanakan pengabdian kepada masyarakat adalah berupa:

1. Sosialisasi mitigasi bencana banjir di sekitar Daerah Aliran Sungai melalui penanaman pohon di sekitar Daerah Aliran Sungai bagi masyarakat.

2. Aksi penanaman pohon yang dilakukan oleh anggota pengabdian beserta masyarakat di sekitar Daerah Aliran Sungai.

\section{HASIL DAN PEMBAHASAN}

Pengabdian pada Masyarakat di Nagari Sungai Durian Kecamatan Patamuan Padang Pariaman dilaksanakan dari tanggal 15 April 2019 sampai Juli 2019 dengan persentase 100\% selesai. Adapun kegiatan-kegiatan yang telah dilakukan oleh tim pengabdian pada masyarakat tersebut antara lain melakukan sosialisasi berupa pemahaman tentang penanaman pohon untuk mitigasi bencana banjir baik yang dilakukan di halaman rumah, pekarangan rumah maupun di pinggiran sungai yang ada di Nagari Sungai Durian tersebut. Awalnya tim mengurus surat administrasi dan kerjasama dengan birokrasi setempat dan meminta wali Nagari untuk bekerjasama dalam melaksanakan pengabdian, alhamdulilah Wali Nagari bersedia untuk bekerjasama, begitu pula ketua pemudanya menyambut sosialisasi dan aksi penenman pohon ini dengan baik. Seminggu setelah persetujuan kerjasama di setujui, maka kami tim malakukan sosialosasi kepada masyarakat dengan disertai aksi penamanan pohon tersebut.

Ketua PKM menginginkan adanya bantuan bibit dari Balai Pengelolaan DAS dan Hutan 
Lindung Agam Kuantan, sebanyak 100 batang. Oleh sebab itu Ketua membuat surat permohonan kepada Kepala Balai Pengelolaan DAS dan Hutan Lindung Agam Kuantan dengan persetujuan dari Ketua Prodi Pendidikan Geografi (Ibu Erna Juita, M.Si). Setelah itu Ketua mengantarkan surat ke Balai untuk di proses beserta proposalnya.

Pohon yang kami tanam merupakan bibit unggul tanaman produktif yang kami peroleh dari Balai Pengelolaan DAS dan Hutan Lindung Agam Kuantan yang berkantor di Jl Khatib Sulaiman, Padang. Pertama ketua PKM mengusulkan untuk meminta bibit unggul yang akan di tanam di Nagari Sungai Durian dengan alasan bahwa Nagari tersebut membutuhkan pohon untuk menahan laju air di sekitar sungai atau di pinggiran sungai, dengan melakukan pembuatan proposal yang di ajukan ke kepala Balai. Setelah disetujui maka ketua PKM menjemput DO bibit ke Kecamatan Kuranji sebanyak 100 batang. Tanaman bibit ini adalah jenis stek dan unggul untuk ditanam. Tanaman yang kami usulkan terdiri dari 6 jenis yaitu:
1. Mangga 20 Batang
2. Durian 20 Batang
3. Manggis 20 Batang
4. Alpokat 10 Batang
5. Jambu Bol 10 Batang
6. Jambu Air 10 Batang

Semua bibit di angkut menggunakan mobil ke lokasi, besoknya barulah di lakukan penanaman pohon tersebut.

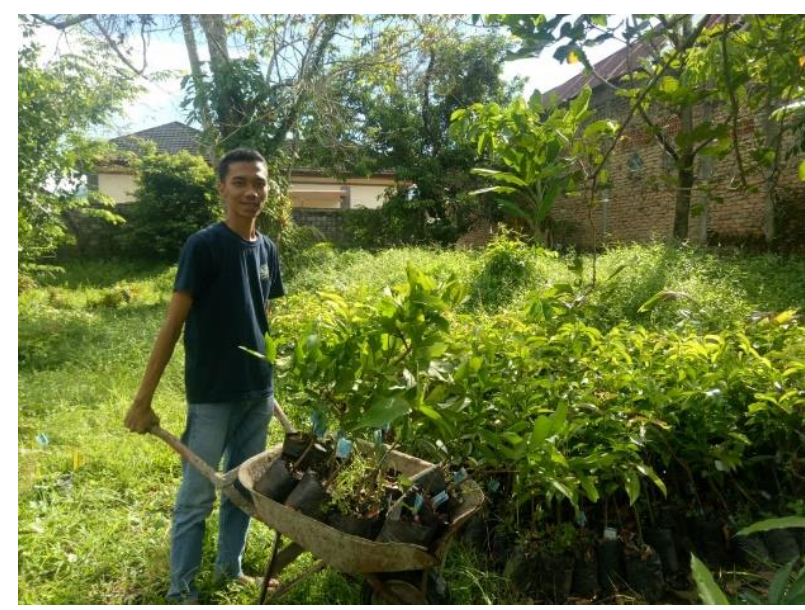

Gambar 1. Penjemputan bibit oleh anggota pengabdian di pembibitan Balai Pengelolaan DAS dan Hutan Lindung Agam Kuantan.

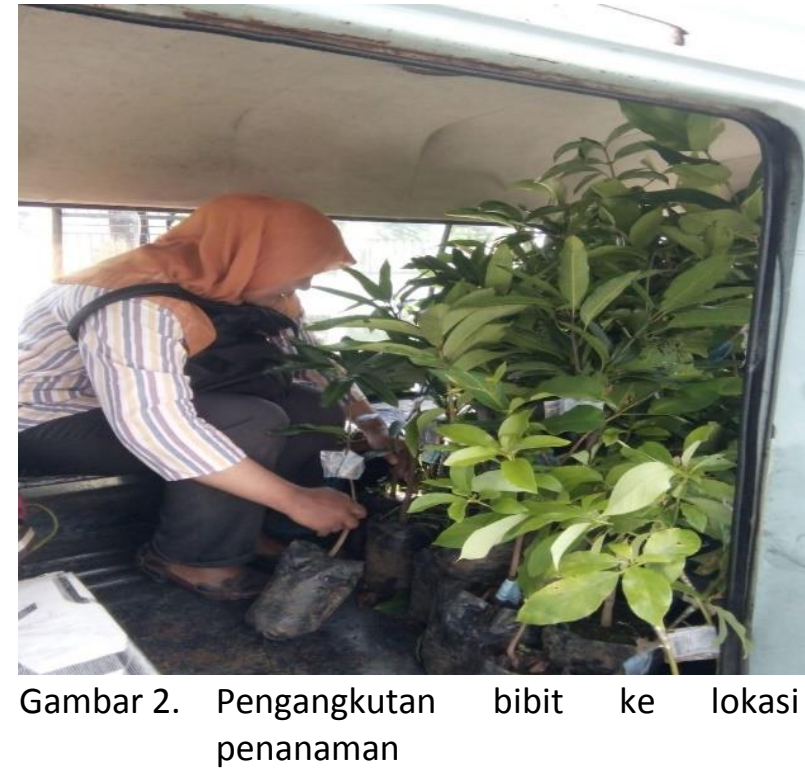

Pengangkutan bibit ke tempat pengumpulan sementara untuk di tindak lanjuti ke daerah pengabdian. Sesuai dengan kesepakatan yang telah ditentukan, maka pada tanggal 25 April 2019, dilaksanakan PKM tahap pertama, yang terdiri dari beberapa penyuluhan yang dilakukan oleh tim ahli. Penyuluhan dilakukan oleh tim pengabdian untuk melaksanakan kegiatan. Penyuluhan yang dilakukan adalah terkait dengan mitigasi bencana banjir melalui penanaman pohon. Mitigasi ini penting dilakukan oleh masyarakat untuk menhindari terjadinya banjir, agar memperbanyak adanya infiltrasi melalui akar tanaman dari pada banyaknya run off di permukaan ketika terjadinya hujan yang berkepanjangan. Gerakan penanaman pohon ini untuk memberikan contoh kepada masyarakat bahwa banyaknya dunia perguruan tinggi yang peduli terhadap lingkungan hidup dan mencegah terjadinya banjir memalui penanaman pohon. Masyarakat juga diperbolehkan bertanya terkait dengan mitigasi banjir ini, ternyata ada masyarakat yang bertanya kalau semua pekatangan mereka ditanami pohon maka akan banyak sampah dari pohon tersebut yang harus di bersihkan, maka kami menjelaskan kalau sampah dari pohon itu akan menjadi pupuk bagi tanaman jika di letekkan saja atau di kumpul di bawah pohon lala kelamaan akan menjadi humus dan pupuk alami untuk kesubutan tanaman. Maka akan terjadi daur ulang atau siklus ekologi tumbuhan.

Pengetahuan tentang bancana sangat dibutuhkan oleh masyarakat di Nagari ini. Bencana merupakan rangkaian dari peristiwa yang 
mengancam kehidupan masyarakat yang disebabkan oleh faktor alam atau faktor non alam sehingga menimbulkan korban manusia, kerusakan lingkungan, kerugian harta benda, dan dampak psikologis bagi masyarakat. (Pasal 1 ayat 1 UU nomor 24 tahun 2007). Rachmat (2005) menyatakan bahwa mitigasi adalah suatu tahapan yang bertujuan untuk mengurangi kemungkinan dampak negatif kejadian bencana terhadap kehidupan dengan menggunakan cara alternatif yang lebih dapat diterima secara ekologi. Bencana ini bisa berupa gempa bumi, tsunami, banjir, longsor, kebakaran, angin puting beliung, wabah penyakit maupun kecelakaan lalu lintas dan lainnya.

Daerah rawan bencana, penanggulangan bencana harus dimulai dari tahap mitigasi bencana. Mitigasi merupakan upaya untuk mengurangi risiko bencana, baik

melalui penyuluhan, penyadaran, motivasi, kerjasama dan peningkatan kemampuan menghadapi ancaman bencana. Resiko bencana merupakan potensi kerugian yang ditimbulkan akibat bencana pada suatu wilayah dan kurun waktu tertentu berupa kematian, luka, sakit, jiwa terancam, sehingga hilangnya rasa aman. mengungsi, kerusakan atau kehilangan harta, akhirnya mengganggu aktivitas masyarakat. Kegiatan mitigasi dapat dilakukan melalui sosialisasi bagaimana menghadapi bencana, simulasi evakuasi bencana, rambu-rambu rawan bencana, membuat jalur evakuasi, pendidikan dan pelatihan menghadapi dan mengurangi dampak bencana, dan lain sebagainya.

Mitigasi bencana bisa berupa mitigasi fisik dan mitigasi non fisik. Mitigasi fisik (Structure Mitigation) adalah upaya yang dilakukan untuk mengurangi risiko bencana dengan menurunkan kerentanan atau meningkatkan kemampuan menghadapi ancaman bencana dengan membangun infrastruktur. Sedangkan mitigasi non fisik merupakan (Nonstructure Mitigation) adalah upaya yang dilakukan untuk mengurangi risiko bencana dengan menurunkan kerentanan atau meningkatkan kemampuan menghadapi ancaman bencana dengan meningkatkan kapasitas pemerintah dan masyarakat dalam menghadapi bencana (Pergub. Sumatera Barat nomor 118 tahun 2008).

Bencana banjir disebabkan oleh faktor alam dan kegiatan manusia yang terkait dengan pemanfaatan sumberdaya alam yang menyebabkan degradasi dan kerusakan DAS, Nugroho (2015). Faktor alam terutama disebabkan intensitas curah hujan yang sangat tinggi dan kondisi karakteristik DAS, sedangkan faktor manusia disebabkan adanya perubahan penggunaan lahan, sarana prasarana drainase belum baik serta sosial kelembagaan pemerintah dan masyarakat belum mantap. Banjir menimbulkan dampak kerusakan dan kerugian bisa berupa korban manusia dan harta benda sehingga mengganggu bahkan melumpuhkan kegiatan sosial-ekonomi penduduk, Puturuhu (2015). Bencana banjir juga telah menimbulkan banyak kerusakan lingkungan, baik lingkungan alami (erosi tebing, sedimentasi, pendangkalan sungai), maupun lingkungan buatan (kerusakan/kerugian sektor pertanian, pemukiman, sarana umum), Suherlan (2001). Sehingga bencana banjir perlu mendapat perhatian khusus, karena bencana tersebut menelan korban jiwa dan kerugian terbesar (40\%) dari seluruh kerugian bencana alam, Kingma (1991). Upaya pengendalian bencana banjir yang telah dilakukan pemerintah masih didominasi dengan pendekatan struktur (bangunan teknis), sedangkan pendekatan non struktur masih jarang dilakukan. Menurut Badan Nasional Penanggulangan Bencana (BNPB), paradigma baru pengendalian bencana lebih menekankan pada pengurangan resiko bencana (mitigasi). Mitigasi merupakan serangkaian upaya untuk mengurangi resiko bencana, baik melalui pembangunan fisik maupun penyadaran dan peningkatan kemampuan menghadapi ancaman bencana, menurut undang-undang Republik Indonesia nomor 4 Tahun 2007. Masyarakat merupakan pihak pertama yang berhadapan dengan resiko bencana sehingga kapasitas mitigasi bencana lebih efektif dengan partisipasi masyarakat. Salah satu hal yang harus diperhatikan dalam upaya mitigasi, yaitu tersedianya informasi dan peta daerah rawan bencana serta sosialisasi untuk meningkatkan kesadaran masyarakat dalam menghadapi bencana, Anna, dkk (2015).

Diperlukan juga suatu penanganan dalam manajemen bencana, yaitu dimana seluruh kegiatan yang meliputi aspek perencanaan dan penanggulangan bencana, pada sebelum, saat dan sesudah terjadi bencana dimana di kenal dengan "Siklus Manajemen Bencana". Menurut Agus 
Rahmat (2005) secara umum kegiatan manajemen bencana dapat dibagi dalam kedalam tiga kegiatan utama, yaitu:

1. Kegiatan pra bencana yang mencakup kegiatan pencegahan, mitigasi, kesiapsiagaan, serta peringatan dini

2. Kegiatan saat terjadi bencana yang mencakup kegiatan tanggap darurat untuk meringankan penderitaan sementara, seperti kegiatan search and rescue (SAR), bantuan darurat dan pengungsian

3. Kegiatan pasca bencana yang mencakup kegiatan pemulihan, rehabilitasi, dan rekonstruksi.

Berdasarkan Konferensi Pengurangan Bencana Dunia, substansi dasar yang merupakan prioritas kegiatan mitigasi sampai tahun 2015, antara lain:

1. Meletakkan pengurangan risiko bencana sebagai prioritas nasional maupun daerah yang pelaksanaannya harus didukung oleh kelembagaan yang kuat.

2. Mengidentifikasi, mengkaji dan memantau risiko bencana serta menerapkan sistem peringatan dini.

3. Memanfaatkan pengetahuan, inovasi dan pendidikan untuk membangun kesadaran keselamatan diri dan ketahanan terhadap bencana pada semua tingkatan masyarakat.

4. Mengurangi faktor-faktor penyebab risiko bencana.

5. Memperkuat kesiapan menghadapi bencana pada semua tingkatan masyarakat agar respons yang di lakukan lebih efektif.

Menurut Agus Rahmat (2005), mitigasi bencana yang efektif harus memiliki tiga unsur utama, yaitu penilaian bahaya, peringatan dan persiapan.

1. Penilaian bahaya (hazard assestment); diperlukan untuk mengidentifikasi populasi dan asset yang terancam, serta tingkat ancaman. Penilaian ini memerlukan pengetahuan tentang karakteristik sumber bencana, probabilitas kejadian bencana, serta data kejadian bencana dimasa lalu. Tahapan ini menghasilkan Peta Potensi Bencana yang sangat penting untuk merancang kedua unsur mitigasi lainnya.

2. Peringatan (warning); diperlukan untuk memberi peringatan kepada masyarakat tentang bencana yang akan mengancam (seperti bahaya tsunami yang diakibatkan oleh gempa bumi, aliran lahar akibat letusan gunung berapi, dsb). Sistem peringatan didasarkan pada data bencana yang terjadi sebagai peringatan dini serta menggunakan berbagai saluran komunikasi untuk memberikan pesan kepada pihak yang berwenang maupun masyarakat. Peringatan terhadap bencana yang akan mengancam harus dapat dilakukan secara cepat, tepat dan dipercaya.

3. Persiapan (preparedness). Kegiatan kategori ini tergantung kepada unsur mitigasi sebelumnya (penilaian bahaya dan peringatan), yang membutuhkan pengetahuan tentang daerah yang kemungkinan terkena bencana dan pengetahuan tentang sistem peringatan untuk mengetahui kapan harus melakukan evakuasi dan kapan saatnya kembali ketika situasi telah aman.

Pengetahuan dan pemahaman masyarakat yang masih rendah dalam menghadapi bencana dapat diminimalisir dengan melakukan sosialisasi tentang kesiapan masyarakat dalam menghadapinya, Nefilinda, dkk (2019). Sosialisasi mitigasi bencana ini perlu dilakukan agar masyarakat tanggap, tangkas dan cepat sehingga dapat menghindari jatuhnya korban bencana menurut Nefilinda, dkk (2019). Setelah dilakukan sosialisasi maka pada kesepakatan pertemuan berikutnya dengan aksi penanaman pohon di sekitar Dearah Aliran Sungai, yang merupakan lahan milik masyarakat yang dilakukan oleh tim PKM:

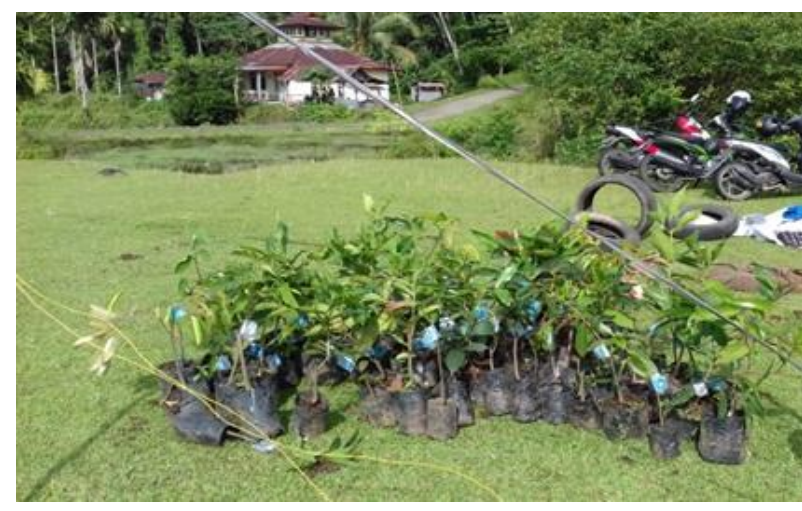

Gambar 3. Bibit tiba di lokasi dan beberapa jenis pohon yang akan di tanam 


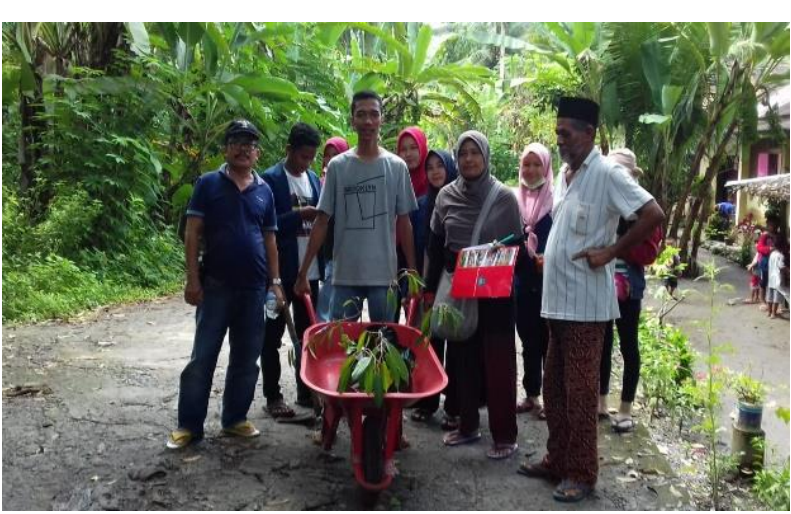

Gambar 4. Melakukan kerjasama dengan pemuka adat agar dapat melakukan sosialisasi kepada masyarakat

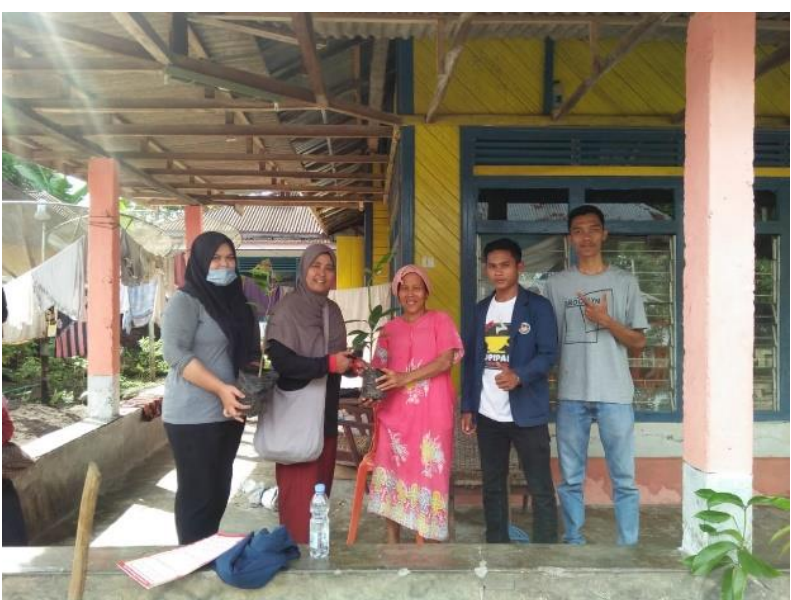

Gambar 5. Sosialisasi dan menyerahkan pohon untuk di tanam di lahan masyarakat yang ada di sekitar Daerah Aliran Sungai

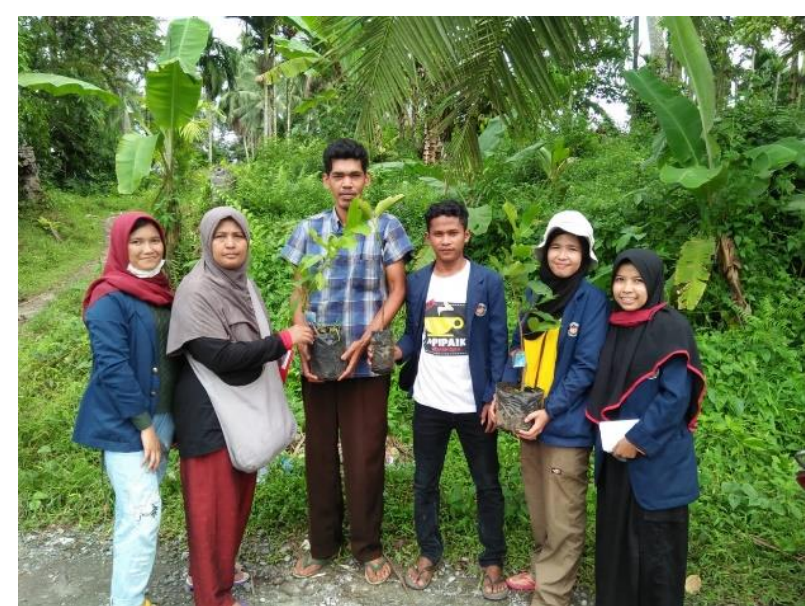

Gambar 6. Sosialisasi dan Menyerahkan pohon untuk di tanam di lahan masyarakat yang ada di sekitar Daerah Aliran Sungai

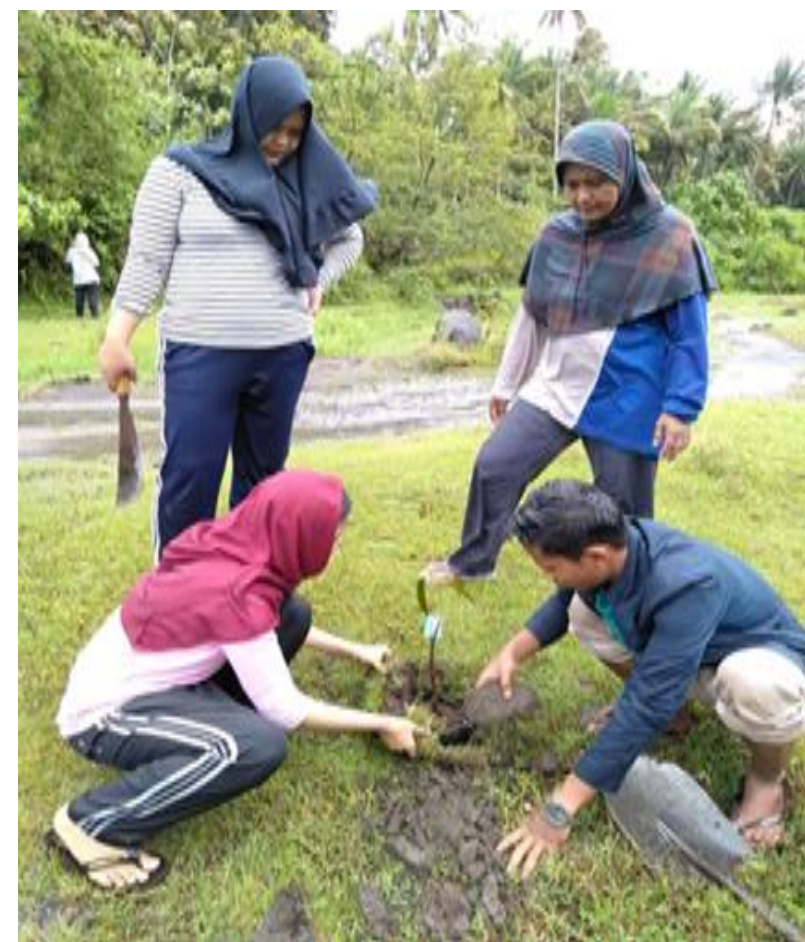

Gambar 7. Melakukan aksi penanaman pohon di sekitar DAS

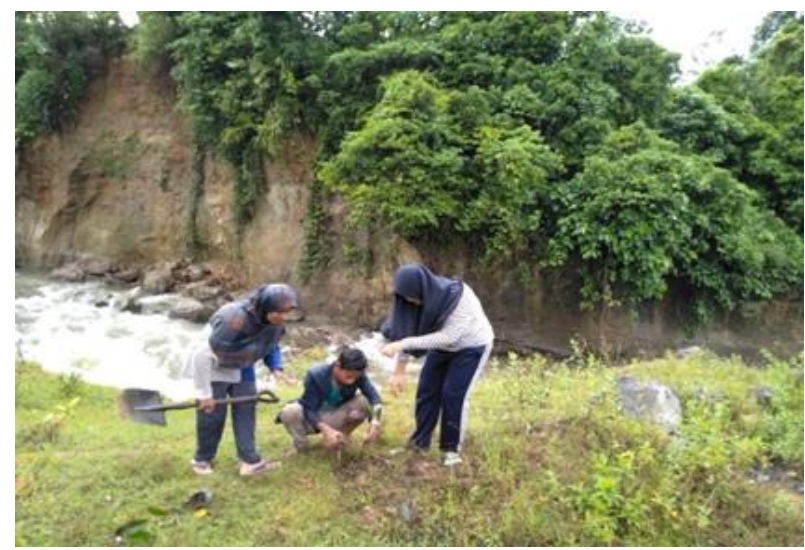

Gambar 8. Anggota pengabdian menanam pohon di pinggir sungai

Menurut Undang-Undang Nomor 24 Tahun 2007 tentang penanggulangan bencana harus mengaplikasikan prinsip cepat, tepat, praktis, koordinasi dan keterpaduan, berdaya guna dan hasil guna, transparansi dan akuntabilitas, kemitraan, pemberdayaan non diskriminasi dan non proletisi. Sedangkan menurut Staf Menteri Sosial (2008) menyatakan pentingnya pemberdaan masyarakat dalam penanggulangan bencana yaitu: 1) efisiensi, hasil yang dicapai lebih optimal dengan memanfaatkan sumberdaya manusia yang tersedia, 2) efektivitas, diharapkan manggunakan alternative kebijakan dapat mempercepat 
tercapainya tujuan fungsional dalam penanggulangan bencana yaitu: ketepatan, kecepatan dan kesesuaian, 3) keberlanjutan, menjadi kegiatan yang dilakukan secara rutin karena membutuhkan penaggulangan secara berkelanjutan.

Strategi pemberdayaan masyarakat dalam penaggulangan bencana menurut Enok Maryani (2009) antara lain: 1) pemanfaatan nilai-nilai lokal dan pengetahuan masyarakat setempat yang terkait dengan penaggulangan bencana, 2) pemanfaatan inovasi pengetahuan dan Pendidikan untuk membangun budaya keselamatan dan ketahanan pada seluruh tingkatan, 3) pengurangan cakupan resiko bencana alam, 4) mekanisme penaggulangan bencana mencakup: pembentukan resiko bencana alam sebagai prioritas Nasional maupun daerah, peningkatan pemahaman dan pengetahuan masyarakat lokal tentang bencana yang akan terjadi, pembentukan institusi pelaksana yang kuat, terkoordinasi dan efektif, pengadaan dan perbaikan system peringatan dini, pengidentifikasi, pengkajian dan pemantauan bencana alam, peningkatan kesipan menghadapi bencana pada semua tingkatan masyarakat, agar taggap yang dilakukan lebih efektif, sebaiknya lakukan pula kegiatan simulasi bencana, 5) peningkatan kesadaran masyarakat dalam kesiapsiagaan menghadapi bencana, 6) pemberdayaan peran masyarakat dalam menghadapi bencana yang didapat dari pengalaman (proses belajar dari pengalaman sebelumnya), 7) respon pemerintah daerah dan aparatnya dari instansi sector dalam membangun kesiapsiagaan masyarakat, 8) terlatih, terorganisasi dan terkoordinasinya tenaga lokal (Des/Kelurahan) dalam penaggulangan bencana alam, 9) dibangunnya kesamaan persepsi tentang kebencanaan dilingkungan masyarakat.

\section{KESIMPULAN DAN SARAN}

\section{Simpulan}

Sosialisasi mitigasi bencana banjir memalui penanaman pohon di Kenagarian Sungai Durian Kecamatan Patamuan Kabupaten Padang Pariaman dapat tercapai dengan baik, terbukti bahwa masyarakat mau menanam pohon di lahan miliknya. Kegiatan PKM juga dilakukan aksi penanaman 100 batang pohon dengan 6 jenis tanaman produktif.

\section{Saran}

1. Diharapkan kegiatan PKM ini dilakukan secara berkelanjutan agar bermanfaatan bagi masyarakat.

2. Perlunya manajemen yang lebih baik dalam pengelolaan daerah aliran sungai sehingga dapat dilakukan mitigasi bencana banjir oleh masyarakat setempat

3. Agar kegiatan ini dapat berjalan secara berkelanjutan, diharapkan masyarakat dan pemerintah terkait dapat memberikan fasilitas dalam penyaluran dan memantau masyarakat dalam pengelolaan lingkungan hidup terutama yang berdampak terhadap daerah aliran sungai

4. Diharapkan adanya pendampingan dari Dinas Pengelolaan Lingkungan Hidup dan Balai Pengelolaan DAS Agam Kuantan

\section{DAFTAR PUSTAKA}

Anna, Alif N., Suharjo, \& Priyana, Y., (2015), Kajian Biofisik Lahan untuk Penilaian Kerentanan Banjir di DAS Bengawan Solo Hulu, University Research Colloquium 2015 p:9-17.

Kingma, N., (1991), Natural Hazard: GeomorphologicalAspect of Flood Hazard, The Netherlands: ITC.

Maryani Enok. 2009. Model Sosialisasi Mitigasi Pada Masyarakat Daerah Rawan Bencana Di Jawa

Barat. file.upi.edu/Direktori/FPIPS/JUR.../Artikel_MITI GATE_INGG_15-12-2009.pdf

Nefilinda, Slamet Rianto \& Jamsari. (2019). Sosialisasi Pemahaman Kebencanaan di Kelurahan Pasie Nan Tigo, Kecamatan Koto Tangah, Kota Padang. Seminar Nasional Pemberdayaan Masyarakat, Pekanbaru, 201908-21. ISSN 2685-9017. conference.unri.ac.id

Nefilinda, Slamet Rianto \& Jamsari. (2019). Pengabdian Mitigasi Bencana di Kelurahan Pasie Nan Tigo Kecamatan Koto Tangah Kota Padang. Jurnal Rangkiang. UP3M STKIP PGRI Sumatera Barat. ISSN: (2721-2688) Vol. 1, No 2 (Desember 2019): 69. https://doi.org/10.22202/JR.2020.V1i2.3853

Nugroho, S.P., (2015), Relevansi Meningkatnya Bencana Hidrometeorologi terkait Kerusakan DAS di Indonesia, Prosiding Seminar Nasional 
Restorasi DAS: Mencari Keterpaduan di Tengah Isu Perubahan Iklim, Surakarta: BPTKPDAS.

Paimin, Sukresno, \& Pramono, I.B., (2009), Teknik Mitigasi Banjir dan Tanah Longsor, Tropenbos International Indonesia Programme.

Puturuhu, F., (2015), Mitigasi Bencana dan Pengeinderaan Jauh, Cetakan ke 1, Yogyakarta: Graha IImu.

Rachmat, A., 2005, Manajemen dan Mitigasi Bencana. Bandung: BPLHD.
Suherlan, E., (2001), Zonasi Tingkat Kerentanan Banjir Kabupaten Bandung, Skripsi, Fakultas Matematika dan Ilmu Pengetahuan Alam, Institut Pertanian Bogor.

Undang-undang nomor 24 tahun 2007 tentang Penanggulangan Bencana

Undang-undang Republik Indonesia nomor 4 Tahun 2007 tentang Penanggulangan Bencana. 